\title{
Ceftriaxone-induced leucocytoclastic vasculitis
}

\author{
Daniela Andrea Haehn, ${ }^{1}$ Archi Patel, ${ }^{2}$ George Youngberg, ${ }^{2}$ Alexei Gonzalez-Estrada ${ }^{3}$
}

${ }^{1}$ Mayo Clinic Hospital Jacksonville, Jacksonville, Florida, USA

${ }^{2}$ Department of Pathology, East Tennessee State University James H Quillen College of Medicine, Johnson City, Tennessee, USA

${ }^{3}$ Division of Allergy and Clinical Immunology, Department of Medicine, East Tennessee State University James H Quillen College of Medicine, Johnson City, Tennessee, USA

\section{Correspondence to} Dr Alexei Gonzalez-Estrada, gonzalez.alexei@mayo.edu

Accepted 1 April 2019
Check for updates

(C) BMJ Publishing Group Limited 2019. No commercial re-use. See rights and permissions. Published by BMJ.

To cite: Haehn DA, Patel A, Youngberg $\mathrm{G}$, et al. BMJ

Case Rep 2019;12:e229411. doi:10.1136/bcr-2019229411

\section{DESCRIPTION}

A 35-year-old man without history of drug allergy and a medical history of essential hypertension, intravenous drug abuse, and chronic hepatitis C with low viral load presented for evaluation with a 5-day rash in lower extremities associated with crimpling joint pain. The patient had been on ceftriaxone for the last 14 days due to a methicillin-sensitive Staphylococcus aureus tricuspid endocarditis. Patient referred that the rash started as blisters on his ankles that then became purpuric and progressed upwards to involve his lower extremities. On physical examination, multiple non-blanching purpuric lesions limited to lower extremities were noted (figure 1A). Our clinical suspicion was leucocytoclastic vasculitis diagnosis. Skin biopsy was performed showing extravasation of erythrocytes, perivascular neutrophil degeneration and necrosis of the vessels (figure 1B). A diagnosis of leucocytoclastic vasculitis (LCV) was made. The patient was treated with systemic corticosteroids; ceftriaxone was discontinued, and daptomycin was initiated with improvement of the LCV.

LCV is a small vessel of the skin with immune complex that spares internal organs generally secondary to drug exposure or infection. ${ }^{1}$ Half of the cases of LCV have been associated with chronic infections such as hepatitis $\mathrm{B}$ or $\mathrm{C}$ virus, infective endocarditis, infective shunts and HIV. ${ }^{2}$ Histological findings in skin biopsy include vascular and perivascular deposition of neutrophils of the vessels walls, nuclear dust and extravasated erythrocytes. ${ }^{3}$ The diagnosis of LCV is suggested by clinical manifestation and a history of initiation of a new drug or infection. ${ }^{1}$

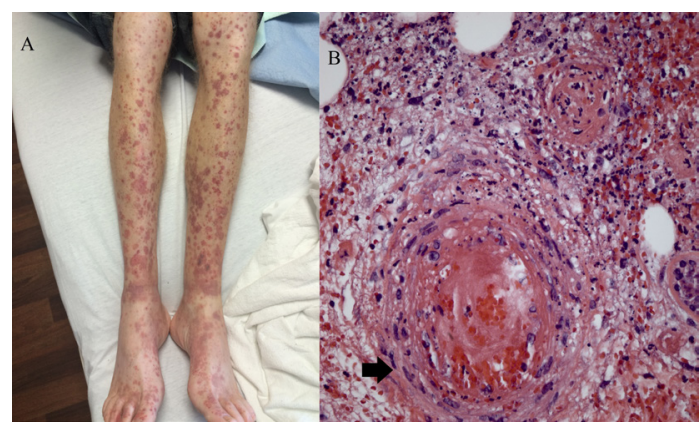

Figure 1 (A) Multiple non-blanching purpuric lesions limited to the lower extremities. (B) Skin biopsy of a purpuric lesion showing extravasation of erythrocytes, perivascular neutrophil degeneration and necrosis of the vessels.

\section{Learning points}

- Leucocytoclastic vasculitis (LCV) most commonly occurs secondary to drugs but can be also secondary to chronic infectious diseases such as hepatitis B or C virus, infective endocarditis and HIV.

- Many medications are commonly implicated causes of LCV, but penicillins, cephalosporins, sulphonamides, phenytoin and allopurinol are the most common agents.

Non-blanching palpable purpura is the most common manifestation, but other skin lesions such as maculopapular rash, bullae, papules, plaques, nodules, ulcers and livedo reticularis can also be present. Skin biopsy confirms the diagnosis. ${ }^{3}$ Management of LCV is directed to treat the underlying cause. An isolated case of LCV by a known trigger should be treated with discontinuation of the trigger. ${ }^{3}$ Chronic, recurrent or severely symptomatic LCV should be treated with azathioprine, mycophenolate mofetil, methotrexate or rituximab should be started. ${ }^{3}$

There is a documented association between hepatitis $\mathrm{C}$, infective endocarditis and initiation of a new drug. We believe that the causative agent in this case was the ceftriaxone since discontinuation of the aetiological agent improved the rash. Unfortunately, the patient was a lost to follow-up.

Contributors DAH: reporting, conception and design, analysis and interpretation of data. AP: reporting, conception and design, acquisition of data or analysis and interpretation of data. GY: planning, conduct, reporting, conception and design, acquisition of data or analysis and interpretation of data. AG-E: planning, conduct, reporting, conception and design, acquisition of data or analysis and interpretation of data.

Funding The authors have not declared a specific grant for this research from any funding agency in the public, commercial or not-for-profit sectors.

Competing interests None declared.

Patient consent for publication Obtained.

Provenance and peer review Not commissioned; externally peer reviewed.

\section{REFERENCES}

1 Cakiter AU, Kucuk OS, Ozkaya DB, et al. Demographic characteristics, aetiology, and assessment of treatment options in leukocytoclastic vasculitis. Postepy Dermatol Alergol 2017:2:104-9.

2 Blanco R, Martínez-Taboada VM, Rodríguez-Valverde V, et al. Cutaneous vasculitis in children and adults: associated diseases and etiologic factors in 303 patients. Medicine 1998;77:403-18.

3 Goeser MR, Laniosz V, Wetter DA. A practical approach to the diagnosis, evaluation, and management of cutaneous small-vessel vasculitis. Am J Clin Dermatol 2014;15:299-306. 
Images in...

Copyright 2019 BMJ Publishing Group. All rights reserved. For permission to reuse any of this content visit https://www.bmj.com/company/products-services/rights-and-licensing/permissions/

BMJ Case Report Fellows may re-use this article for personal use and teaching without any further permission.

Become a Fellow of BMJ Case Reports today and you can:

- Submit as many cases as you like

- Enjoy fast sympathetic peer review and rapid publication of accepted articles

Access all the published articles

- Re-use any of the published material for personal use and teaching without further permission

For information on Institutional Fellowships contact consortiasales@bmjgroup.com

Visit casereports.bmj.com for more articles like this and to become a Fellow 